\title{
ОПТИМАЛЬНИЙ МЕТОД ЛІКУВАННЯ АРТЕРІАЛЬНОї ГІПЕРТЕНЗІї, ПОЄДНАНОЇ $З$ ДИСПЛАЗІЄЮ СПОЛУЧНОЇ ТКАНИНИ
}

\author{
๑Є. Х. Заремба, В. М. Карпляк, Н. О. Рак, О. В. Заремба-Федчишин, О. В. Заремба \\ Львівський національний медичний університет імені Данила Галицького
}

РЕЗЮмЕ. Артеріальна гіпертензія (АГ) є одним із найагресивніших факторів ризику формування та прогресування патології серцево-судинної системи (ССС) з ураженням органів-мішеней та розвитком асоційованих захворювань: ішемічної хвороби серця, гострої та хронічної церебральної патології, системного атеросклерозу, ураження клубочкового апарату нирок з розвитком нефропатії та ниркової недостатності.

Мета дослідження - покращити ефективність лікування хворих на АГ, поєднану з ДСТ, на основі вивчення клінічного перебігу, вираженості зовнішніх і внутрішніх фенотипових ознак ДСТ, активності запалення, системи згортання крові, з застосуванням комбінації ІАПФ та БКК та використанням метаболічної терапії в комплексному лікуванні.

Матеріал і методи. Обстежено 57 хворих (24 жінки та 33 чоловіки) на АГ II - III стадії з проявами ДСТ. Хворі були поділені на 3 групи: I група (основна) - 35 хворих, які, крім базисної терапії, отримували 2-етил-6-метил-3-гідроксипіридину сукцинат (мексикор); II група (порівняння) - 22 хворих, які отримували базисну терапію згідно з клінічним протоколом; III група - 20 практично здорових осіб. До базисної терапії в якості гіпотензивних засобів входила комбінація раміприл/амлодипін (хартил АМ) з титруванням дози залежно від вихідних рівнів АТ, добового моніторингу артеріального тиску (ДМАТ). Обстеження хворих проводили згідно з розробленим нами протоколом: об'єктивний огляд, лабораторні дослідження (коагулограма: протромбіновий час (ПЧ), протромбіновий індекс (ПІ) та загальний фібриноген (ЗФ); визначення С-реактивного протеїну (СРП)), інструментальні методи обстеження (ЕКГ, ехоКГ, ДМАТ, УЗД внутрішніх органів та судин нижніх кінцівок, Уз дуплексне обстеження сонних і хребтових артерій, рентгенологічне дослідження кістково-суглобової системи), консультації офтальмолога, невропатолога, травматолога, стоматолога.

Результати. У результаті проведеного дослідження в хворих на АГ ІІ-ІІІ стадій діагностовано ДСТ різного ступеня вираженості. У І групі хворих ДСТ середнього ступеня тяжкості виявлено в 30 (85,7 \%), у II групі - в 20 (90,9 \%), тяжкого ступеня - в $5(14,3 \%)$ та 2 (9,1 \%) пацієнтів відповідно.

Результати дослідження показали, що до 10 діб лікування в основній групі середньодобові САТ і ДАТ знижувалися на 15,6 \% і 17,5 \% відповідно, а до 30 діб - на 25,2 \% і 26,4 \%. Після застосування раміприлу/амлодипіну та 2-етил-6-метил-3-гідроксипіридину сукцинату в комплексному лікуванні хворих на АГ, поєднану з ДСТ, рівень СРП знизився на 42,8 \% на 10 день лікування $(p<0,01)$ та удвічі після 30 днів спостереження. Достовірно змінився

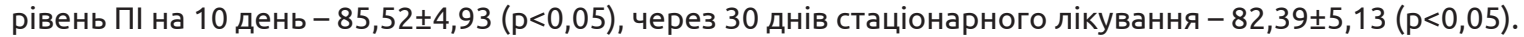

Висновки. Застосування раміприлу/амлодипіну та 2-етил-6-метил-3-гідроксипіридину сукцинату в комплексному лікуванні хворих на АГ, поєднану з ДСТ, покращує клінічний перебіг захворювання, зменшує частоту рецидивів гіпертонічних кризів, знижує кількість ускладнень, призводить до зменшення термінів стабілізації АТ, сприяє нормалізації СРП та показників системи згортання крові.

КлючовІ СлОВА: артеріальна гіпертензія; дисплазія сполучної тканини; раміприл/амлодипін; 2-етил-6метил-3-гідроксипіридину сукцинат.

Вступ. Серцево-судинна патологія (ССП) займає перше місце серед причин смертності, інвалідності та непрацездатності населення. У 2016 р. кількість хворих із патологією систем кровообігу склала 22303564 особи, з нихна АГ-10421 402 особи, працездатних - 4573718 осіб (43,9 \% дорослих) $[1,2]$. АГ $є$ одним із найагресивніших факторів ризику формування та прогресування патології ССС з ураженням органів-мішеней та розвитком асоційованих захворювань: ішемічної хвороби серця, гострої та хронічної церебральної патології, системного атеросклерозу, ураження клубочкового апарату нирок з розвитком нефропатії та ниркової недостатності.

Основою формування АГ, поєднаної з ДСТ, $\epsilon$ дисфункція судинного ендотелію артеріального кровообігу, вираження якої залежить від тривалості, ступеня тяжкості АГ, наявності атерогенних дисліпідемій, ефективності антигіпертензивної терапії та її ангіопротекторної активності. Зміни в ССС можна умовно поділити на 2 групи, обумовлені ДСТ та змінами в органах кровообігу, викликані патологічними процесами, що виникли на основі неспроможності сполучних структур. Одним із факторів ризику АГ, що залишається недостатньо вивченим, $є$ патологія колагену - недиференційована дисплазія сполучної тканини (НДСТ) [3]. Наявність сполучної тканини в усіх органах і системах, спільність її походження з мезенхіми, 3 гладкою мускулатурою, кров'ю та лімфою, призводять до виникнення диспластичних змін в будь-якому органі та системі $[4,5]$. НДСТ характеризується змінами колагенових, еластичних фібрил, глікопротеїдів, протеогліканів і фібробластів, в основі яких лежать спадкові мутації генів, які кодують синтез і просторову організацію кола- 
Огляди літератури, оригінальні дослідження, погляд на проблему, ювілеї

гену, структурні білки, білково-вуглеводні комплекси, мутації генів, ферментів і кофакторів до них [6].

АГ, поєднана з ДСТ, супроводжується вираженою ендотеліальною дисфункцією, яка знижує ефективність антигіпертензивної терапії та сприяє розвитку атеросклерозу. На фоні переважання процесів вазоконстрикції над вазодилатацією розвиваються порушення мікроциркуляції, зменшується діаметр мікросудин. Зниження генерації оксиду азоту призводить до дисбалансу про- та антиоксидантних систем ендотелію, що, в свою чергу, посилює розвиток атеросклерозу та сприяє порушенню функціонування ендотеліального рецепторного апарату.

АГ впливає на ремоделювання серця та судин, гіпертрофію міокарда, збільшення розміру та маси кардіоміоцитів, виникнення ендотеліальної дисфункції судинної стінки, прискорення розвитку системного атеросклерозу. При АГ виникають дистрофічні зміни в кардіоміоцитах і гладеньких м'язах судин, що призводить до порушення морфологічної структури та функції як серцевого м'яза, так і судин. Антигіпертензивні засоби знижують AT, але не завжди запобігають негативним змінам у міокарді та судинах $[7,8]$. Згідно з рекомендаціями з АГ Європейського товариства гіпертензії (European Society of Hypertension (ESH) та Європейського товариства кардіологів (Euгореan Society of Cardiology (ESC)) 2013 року, запропоновано 5 основних класів антигіпертензивних препаратів, які доцільно застосовувати як у моно-, так і у

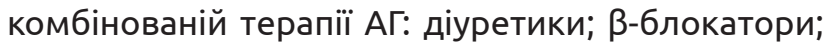
антагоністи кальцію; блокатори ангіотензинових рецепторів; блокатори ангіотензинперетворювального ферменту. До додаткової групи відносять а-адреноблокатори (празозин, доксазозин, теразозин), агоністи центральних а-адренорецепторів (клофелін, метилдофа), симпатолітики (резерпін, раунатин), агоністи імідазолінових рецепторів (моксонідин), судинорозширювальні медикаменти (дибазол, папаверину гідрохлорид, дротаверин, магнію хлорид, інгібітори реніну (аліскірен)) [9]. Комбінація ІАПФ і блокаторів кальцієвих каналів (БКК) протягом багатьох років успішно застосовується в антигіпертензивній терапії. БКК мають легкий діуретичний ефект, підвищують активність симпатичної нервової системи та ренінангіотензин-альдостеронової системи (РААС). ІАПФ зменшують ці ефекти, запобігають набрякам - побічний вплив дигідропіридинових БКК. Обидва класи лікарських засобів $\epsilon$ метаболічно нейтральними та не викликають побічних ефектів з боку центральної нервової системи. В угорському проспективному дослідженні IV фази RAMONA оцінювали ефективність та безпечність фіксованої комбінації раміприлу й амлодипіну в різних дозах у раніше лікованих хворих на АГ ( $n=6423)$, які не досягли цільового рівня АТ на фоні попередньої антигіпертензивної терапії. На завершальному етапі дослідження середній АТ (157/91 мм рт. ст. на момент включення) знизився на 26,4/11,8 мм рт. ст. Завдяки лікуванню фіксованою комбінацією раміприлу/амлодипіну 52,4 \% пацієнтів досягли цільового АТ [10]. Таким препаратом вибору став хартил-АМ (раміприл/амлодипін) в індивідуально підібраних дозах: 5/5; 5/10; 10/5; 10/10 відповідно. Лікувальний засіб блокує надходження іонів Са через канали L-типу (повільні кальцієві канали) мембран в клітини гладких волокон серця і судин, що має прямий розслаблювальний вплив на гладкі м'язи судин, сприяє зниженню артеріального тиску та зменшує ішемію (недостатнє кровопостачання тканин) при стенокардії, знижує споживання енергії, потребу тканин у кисні.

3 метою корекції ендотеліальної дисфункції у пацієнтів з АГ широко застосовують кардіоцитопротекторні засоби. Механізм їх дії включає покращення клітинного енергетичного метаболізму та зменшення вмісту пероксидів у судинній стінці та крові. В основі оптимізації енергетичного метаболізму лежить здатність кардіоцитопротекторів стимулювати окиснення глюкози, як найвигідніший, з погляду економії кисню, шлях генерації енергії. Одним з таких лікарських засобів $є$ мексикор (2-етил-6-метил-3-гідроксипіридину сукцинат). На відміну від інших кардіоцитопротекторів, 2-етил-6-метил-3-гідроксипіридину сукцинат має високу антиоксидантну активність завдяки вмісту емоксипіну. Емоксипін $\epsilon$ "скевенджером" (поглиначем) з широким спектром біологічної дії: інгібує вільнорадикальне окиснення, активно взаємодіє з перекисними радикалами ліпідів, гідроксильними радикалами пептидів, стабілізує клітинні мембрани. Крім того, він знижує агрегацію тромбоцитів і нейтрофілів, зменшує полімеризацію фібрину, гальмує перехід фібрину-мономера у фібрин-полімер, інгібує фосфодіестеразу циклічних нуклеотидів, збільшує вміст циклічних аденозинмонофосфату і гуанідинмонофосфату в клітинах; також емоксипін $\epsilon$ провідником екзогенного сукцинату крізь біологічні мембрани [11]. Відмінністю 2-етил6-метил-3-гідрооксипіридину сукцинату від інших міокардіальних цитопротекторів (триметазидину, мілдронату) $\epsilon$ його здатність прямо підвищувати енергосинтезувальну функцію мітохондрій шляхом збільшення постачання та споживання сукцинату ішемізованими клітинами, реалізацією феномена швидкого окиснення янтарної кислоти сукцинатдегідрогеназою, а також активацією мітохондріального дихального ланцюга, що зумовлюєшвидкий ресинтез аденозинтрифосфату (АТФ) $[12,13]$. 
Огляди літератури, оригінальні дослідження, погляд на проблему, ювілеї

Перевага 2-етил-6-метил-3-гідроксипіридину сукцинату при лікуванні АГ, поєднаної з ДСТ, зумовлена наявністю парентеральної форми засобу, застосування якої дозволяє швидко створити терапевтичну концентрацію й отримати клінічний ефект.

Мета дослідження - покращити ефективність лікування хворих на АГ, поєднану з ДСТ, шляхом вивчення клінічного перебігу, вираження зовнішніх і внутрішніх фенотипових ознак ДСТ, ак- тивності запалення, системи згортання крові 3 застосуванням комбінації ІАПФ та БКК з використанням метаболічної терапії в комплексному лікуванні.

Матеріал і методи дослідження. Проведено обстеження 57 хворих (24 жінки та 33 чоловіки) на АГ II - III стадій з проявами ДСТ, які перебували на стаціонарному лікуванні в кардіологічному відділенні Комунальної міської клінічної лікарні швидкої медичної допомоги Львова. Клінічна характеристика пацієнтів наведена в таблиці 1.

Таблиця 1. Клінічна характеристика хворих при поступленні в стаціонар

\begin{tabular}{|l|c|c|}
\hline \multicolumn{1}{|c|}{ Показники } & $\begin{array}{c}\text { Основна група } \\
(\mathrm{n}=35)\end{array}$ & $\begin{array}{c}\text { Група порівняння } \\
(\mathrm{n}=22)\end{array}$ \\
\hline Вік, років & $59,87 \pm 2,73^{* *}$ & $62,91 \pm 3,32^{* *}$ \\
\hline Тривалість АГ, років & $11,9 \pm 1,3^{*}$ & $12,4 \pm 1,2^{*}$ \\
\hline Ускладнення, АГ & $32(91,4 \%)$ & $20(90,9 \%)$ \\
\hline Систолічний АТ, мм рт. ст. & $205 \pm 29$ & $203 \pm 25$ \\
\hline Діастолічний АТ, мм рт. ст. & $112 \pm 18$ & $111 \pm 16$ \\
\hline
\end{tabular}

Примітки: 1. * - p<0,05; 2. ** - p<0,001 - достовірність різниці показників порівняно з даними до лікування.

Пацієнти були поділені на 3 групи: I група (основна) - 35 хворих на АГ, поєднану з ДСТ, які, крім базисної терапії, отримували 2-етил-6-метил3-гідроксипіридину сукцинат згідно з розробленою методикою; II група (порівняння) - 22 хворих на АГ, поєднану з ДСТ, які отримували базисну терапію згідно з клінічним протоколом; III група 20 практично здорових осіб.

В обстеження не включали хворих із порушеннями ритму, ендокринною патологією (цукровий діабет, захворювання щитоподібної залози тощо), новоутвореннями, нирковою, печінковою та дихальною недостатністю.

Обстеження хворих проводили згідно з розробленим нами протоколом: об'єктивний огляд, лабораторні дослідження (коагулограма: протромбіновий час (ПЧ), протромбіновий індекс (ПІ) та загальний фібриноген (ЗФ); визначення С-реактивного протеїну (СРП)), інструментальні методи о6стеження (ЕКГ, ехоКГ, ДМАТ, УЗД внутрішніх органів та судин нижніх кінцівок, УЗ дуплексне обстеження сонних і хребтових артерій, рентгенологічне дослідження кістково-суглобової системи), консультації офтальмолога, невропатолога, травматолога, стоматолога.

Дослідження проводили тричі: при поступленні хворого в стаціонар, в день виписування зі стаціонару (на 10 день стаціонарного лікування) та через 30 днів після виписування хворого зі стаціонару.

Виявлення зовнішніх ознак ДСТ в хворих на АГ проводили за допомогою антропометричних методів дослідження (оцінка будови тіла, стану шкіри, м'язів, розрахунок індексу Кетле, виявлення доліхостеномелії, плоскостопості, деформацій хребта та грудної клітки, гіпермобільності суглобів). Результати оцінювали за допомогою таблиці діагностичних коефіцієнтів ознак ДСТ та малих аномалій розвитку (за Яковлевим В. М. та співавт., 2008). При досягненні діагностичного порогу 21 бал формулювали висновок про наявність ДСТ. Для визначення ступеня вираженості ДСТ використовували таблиці значимості клінічних маркерів (Кадурина Т. М., Аббакумова Л. Н., 2008). Ступінь тяжкості ДСТ у кожного хворого встановлювали за сумою балів: легкий ступінь ДСТ - сума балів < 20, середній - 21-40, тяжкий - 41 і більше.

Ми розробили алгоритм застосування метаболічної терапії (2-етил-6-метил-3-гідроксипіридину сукцинату) при комплексному лікуванні хворих на АГ, поєднану з ДСТ: 200 мг 2 рази на день в/м протягом 10 днів, потім наступні 30 днів амбулаторного лікування, по 100 мг 3 рази на день, рег os. B базисну терапію як гіпотензивний препарат входила комбінація раміприл/амлодипін з титруванням дози залежно від вихідного рівня АТ, добового моніторингу артеріального тиску (ДМАТ).

Статистичну обробку результатів проводили з використанням програми Microsoft Office Excel 2007 та "Statistica 10.0". Достовірність результатів оцінювали за допомогою t-критерію Стьюдента. Різницю показників вважали достовірною при $\mathrm{p}<0,05$.

Результати й обговорення. В результаті проведеного дослідження в хворих на АГ II - III стадій діагностовано ДСТ різного ступеня вираження. У І групі хворих ДСТ середнього ступеня тяжкості виявлена в 30 (85,7\%), у II групі - в 20 (90,9\%), тяжкого ступеня вираження - у 5 (14,3\%) та 2 $(9,1 \%)$ пацієнтів відповідно. 
Огляди літератури, оригінальні дослідження, погляд на проблему, ювілеї

При виявленні зовнішніх фенотипових ознак у хворих на АГ найчастішими проявами ДСТ були шкірні стрії, які в I групі були у 81,8 \%, в ІІ - у 60 \%, гіпермобільність суглобів легкого ступеня спостерігали в I групі - 25 \%, II - в 20 \%. Патологію хребта у вигляді сколіозу легкого ступеня спостерігали в обох групах хворих. Іншою найпоширенішою зовнішньою ознакою ДСТ була плоскостопість, наявна в I групі у 81,8 \%, в II - у 60 \% хворих. Зовнішній вигляд хворих на АГ доповнювали стигми дизембріогнезу, серед яких макродактилія першого пальця стопи в I групі була в 80 \% осіб, ІІ - в 60 \% хворих.

Серед внутрішніх ознак ДСТ у хворих на АГ найчастіше спостерігали аномальні хорди в шлуночках серця (АХШС), які в I групі хворих були у 45,5 \%, в II - у 40 \% осіб, що вказує на неповноцінність сполучної тканини серця. Патологія органа зору у вигляді ангіопатії сітківки траплялася в І групі в 90 \%, в ІІ -у 60 \% хворих. Аномалії жовчного міхура (перегини, перетинки) в I групі діагностовано у 60 \%, в II - у 18,2 \% хворих. Уроджену мальформацію судин головного мозку спостерігали в I та II групах - у 60 \% хворих.

У результаті проведеного аналізу встановлено, що комплексне лікування хворих на АГ, поєднану $з$ ДСТ, з використанням 2-етил-6-метил-3гідроксипіридину сукцинату нормалізує артеріальний тиск на 10 день лікування у 76,1 \% хворих ( $<<0,01)$, підвищує толерантність до фізичного навантаження у 89,3\% випадків $(p<0,01)$, аналогічні показники при базисній терапії - 68,8 \% та 70,2 \% ( $<<0,05)$ відповідно. На 5 день у 91,3 \% хворих зникли головний біль, головокружіння, нудота, шум у голові, вухах, мушки перед очима, через 10 днів - у 96,7 \% ( $><0,05)$.

Результати дослідження показали, що до 10 діб лікування в основній групі середньодобові САТ і ДАТ знижувалися на 15,6 \% і 17,5 \% відповід- но, а до 30 діб - на 25,2 \% і 26,4%. При монотерапії раміприлом/амлодипіном середньодобові значення САТ і ДАТ знижувалися меншою мірою: до 12-14 діб - на 9,2 \% і 5,2 \% відповідно, до 30 діб на $16,6 \%$ і 11,3\% ( $<<0,05)$. Застосування комбінації 2-етил-6-метил-3-гідроксипіридину сукцинату з раміприлом/амлодипіном у пацієнтів з АГ, поєднаною з ДСТ, приводило до суттєвого прискорення нормалізації рівня АТ і його добового профілю, що свідчило про здатність 2-етил-6-метил-3-гідроксипіридину сукцинату покращувати ендотелійзалежну вазодилатацію і відновлювати функціональну активність ендотелію судин.

При аналізі рівня СРП встановлено, що в обох досліджуваних групах при госпіталізації в стаціонар його рівень був підвищений на 29-30,2 \% $(6,45 \pm 0,83, p<0,001 ; 6,51 \pm 0,78, p<0,001)$.

Після застосування 2-етил-6-метил-3-гідроксипіридину сукцинату рівень СРП мав виражену тенденцію до зниження. На 10 день стаціонарного лікування він зменшився на 42,8 \% $(3,69 \pm 0,68$, p<0,01), а через 30 днів - на 57,5 \% (2,74士0,98, р<0,01) відповідно. При загальноприйнятому лікуванні хворих зниження СРП відбувалося менш інтенсивно й ста-

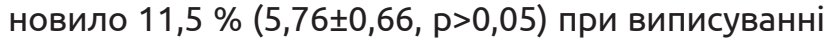
та 50,4 \% $(3,23 \pm 0,89, p>0,05)$ на 30 день лікування.

При госпіталізації в стаціонар у хворих на АГ, поєднану з ДСТ, виявлено зниження ПЧ на 21,6-

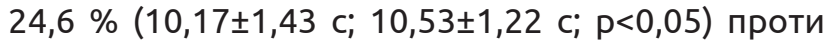
рівня ПЧ у практично здорових осіб $(13,44 \pm 1,63$ с), що свідчить про наявність процесу гіперкоагуляції (табл. 2). У процесі лікування АГ, поєднаної з ДСТ, пЧ у межах норми був лише в основній групі хворих, які отримували 2-етил-6-метил-3-гідроксипіридину сукцинат, встановлено підвищення цього показника на $18,4 \%(12,78 \pm 1,29$ с; $\mathrm{p} \geq 0,05)$ при виписуванні та на 21,2 \% $(14,17 \pm 1,94$ с; р>0,05) у кінці лікування.

Таблиця 2. Показники системи гемостазу в хворих на артеріальну гіпертензію, поєднану з дисплазією сполучної тканини, до лікування

\begin{tabular}{|l|c|c|c|}
\hline \multicolumn{1}{|c|}{ Показники } & $\begin{array}{c}\text { Практично } \\
\text { здорові } \\
\text { особи }\end{array}$ & $\begin{array}{c}\text { І група, хворі на АГ, поєднану } \\
\text { з ДСТ, яким, окрім базисної терапії, } \\
\text { застосовуватимуть 2-етил-6-метил-3- } \\
\text { гідроксипіридину сукцинат }\end{array}$ & $\begin{array}{c}\text { II група хворі на АГ, поєднану } \\
\text { з ДСТ, яким призначатимуть } \\
\text { загальноприйняте лікування }\end{array}$ \\
\hline Протромбіновий час, с & $13,44 \pm 1,63$ & $10,17 \pm 1,43$ & $10,53 \pm 1,22 *$ \\
\hline Протромбіновий індекс, \% & $71,61 \pm 6,86$ & $95,65 \pm 5,36$ & $89,82 \pm 6,32$ \\
\hline Фібриноген, г/л & $2,89 \pm 0,16$ & $4,01 \pm 0,31 * * *$ & $4,19 \pm 0,32 * * *$ \\
\hline
\end{tabular}

Примітки: 1 * - p<0,05; 2 ** - p<0,01; 3 *** - p<0,001 - достовірність різниці показників порівняно з даними до лікування.

На відміну від групи контролю, у якій при виписуванні з лікарні у хворих, які отримували базисне лікування, переважали гіперкоагуляційні процеси, зміни ПЧ при виписуванні зі стаціонару

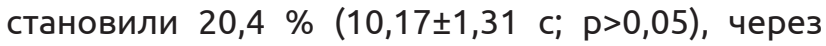
30 днів після стаціонарного лікування рівень Пч


няно з показниками при госпіталізації, і надалі залишався на нижній межі норми (табл. 2).

Іншим показником, що свідчить про загальний зовнішній шлях згортання крові, $€$ ПІ, який в усіх хворих коливався в межах норми (75-100). у 
Огляди літератури, оригінальні дослідження, погляд на проблему, ювілеї

групі хворих на АГ поєднану з ДСТ, які отримували 2-етил-6-метил-3-гідроксипіридину сукцинат, на

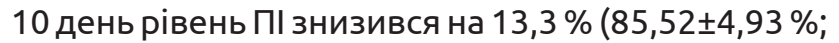
p>0,05) і на $15,5 \%(82,39 \pm 5,13 \% ; p<0,05)$ через
30 днів після стаціонарного лікування (табл. 3). Після базисної терапії ПІ підвищився на 8,5 \% $(82,15 \pm 3,9 \% ; p>0,05)$ і на $1,01 \%(90,73 \pm 4,33 \%$; p>0,05) відповідно (табл. 4).

Таблиця 3. Динаміка показників системи гемостазу в хворих на артеріальну гіпертензію, поєднану з дисплазією сполучної тканини, які отримували базисну терапію з використанням 2-етил-6-метил-3-гідроксипіридину сукцинату

\begin{tabular}{|l|c|c|c|}
\hline \multicolumn{1}{|c|}{ Показники } & $\begin{array}{c}\text { До лікування, при } \\
\text { поступленні хворого } \\
\text { в стаціонар }\end{array}$ & $\begin{array}{c}\text { Після лікування, при } \\
\text { виписуванні хворого } \\
\text { зі стаціонару }\end{array}$ & $\begin{array}{c}\text { Через 30 днів від моменту } \\
\text { переводу хворого } \\
\text { в амбулаторні умови }\end{array}$ \\
\hline Протромбіновий час, с & $10,17 \pm 1,43$ & $12,78 \pm 1,29$ & $14,17 \pm 1,94$ \\
\hline Протромбіновий індекс, \% & $95,65 \pm 5,36$ & $85,52 \pm 4,93^{*}$ & $82,39 \pm 5,13^{*}$ \\
\hline Фібриноген, г/л & $4,01 \pm 0,31$ & $3,71 \pm 0,36$ & $2,49 \pm 0,67^{*}$ \\
\hline
\end{tabular}

Примітка: 1. * - p<0,05; 2. ** - p<0,01; 3 *** - p<0,001 - достовірність різниці показників порівняно з даними до лікування.

Таблиця 4. Динаміка показників системи гемостазу в хворих на артеріальну гіпертензію, поєднану з дисплазією сполучної тканини, які отримували базисне лікування

\begin{tabular}{|l|c|c|c|}
\hline \multicolumn{1}{|c|}{ Показники } & $\begin{array}{c}\text { До лікування, при } \\
\text { поступленні хворого } \\
\text { в стаціонар }\end{array}$ & $\begin{array}{c}\text { Після лікування, } \\
\text { при виписуванні хворого } \\
\text { зі стаціонару }\end{array}$ & $\begin{array}{c}\text { Через } 30 \text { днів після } \\
\text { переводу хворого } \\
\text { в амбулаторні умови }\end{array}$ \\
\hline Протромбіновий час, с & $10,53 \pm 1,22$ & $10,17 \pm 1,31$ & $11,91 \pm 1,69$ \\
\hline Протромбіновий індекс, \% & $89,82 \pm 6,32$ & $82,15 \pm 3,91$ & $90,73 \pm 4,33$ \\
\hline Фібриноген, г/л & $4,19 \pm 0,32$ & $3,82 \pm 0,42$ & $3,69 \pm 0,56$ \\
\hline
\end{tabular}

Примітка: 1. * - p<0,05; 2. ** - p<0,01; 3 *** - p<0,001 - достовірність різниці показників порівняно з даними до лікування.

Рівень фібриногену перевищував показники практично здоровихосіб до лікування $(2,89 \pm 0,16$ г/л)

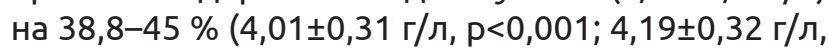
$\mathrm{p} \leq 0,001)$ у хворих на АГ, поєднану з ДСТ.

Достовірну динаміку показників загального фібриногену виявлено в хворих, які приймали 2-етил-6-метил-3-гідроксипіридину сукцинат. Рівень ЗФ у них знизився на 7,5 \% $(3,71 \pm 0,36$ г/л,

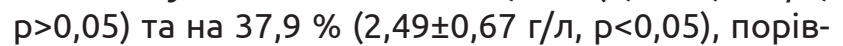
няно з показниками до лікування. У пацієнтів групи контролю, які отримували лише загальноприйняте лікування, позитивні зміни були менш виражені: на 10 день рівень ЗФ знизився на 8,8 \% $(3,82 \pm 0,42$ г/л, р>0,05) та на 11,9\% $(3,69 \pm 0,56$ г/л, p>0,05) через 30 днів після стаціонарного лікування.

Висновки. 1. Використання раміприлу/амлодипіну (в індивідуально підібраній дозі) та 2-етил- 6-метил-3-гідроксипіридину сукцинату в комплексній терапії хворих на АГ, поєднану з ДСТ, покращує клінічний перебіг захворювання, зменшує частоту рецидивів гіпертонічних кризів, знижує кількість ускладнень, призводить до зменшення термінів стабілізації АТ.

2. Комплексне лікування хворих на АГ, поєднану з ДСТ, з застосуванням раміприлу/амлодипіну та 2-етил-6-метил-3-гідроксипіридину сукцинату нормалізує СРП та показники системи згортання крові.

Перспективи подальших досліджень. Подальші дослідження необхідно спрямувати на вивчення прозапальних цитокінів та оксипроліну крові в хворих на АГ, поєднану з ДСТ, з метою вторинної профілактики серцево-судинних захворювань.

\section{ЛІТЕРАТУРА}

1. Державна служба статистики України:Демографічна та соціальна статистика. Охорона здоров'я. Захворюваність населення (за даними Міністерства охорони здоров'я). Режим доступу: http://www.ukrstat.gov.ua/. - 2017.

2. Проблема здоров'я і тривалості життя в сучасних умовах / за ред. В. М. Коваленка, В. М. Корнацького Київ, 2017. - 209 с.

3. Гіперурикемія та сумарний ризик ускладнень у пацієнтів з гіпертонічною хворобою (за даними клінічного дослідження) / С. М. Коваль, В. В. Божко,

М. Ю. Пенкова [та ін.] // Український ревматологічний журнал. - 2010. - № 4. - С. 42-48.

4. Зв'язок між недиференційованою дисплазією сполучної тканини та артеріальною гіпертензією / Є. Х. Заремба, Н. О. Рак, Н. В. Гриб [та ін.] // Здоров'я і суспільство. - 2017. - № 1-2. - С. 139-140.

5. Дисплазия соединительной ткани: основные клинические синдромы, формулировка диагноза, лечение / Г. И. Нечаева, В. М. Яковлев, В. П. Конев [и др.] // Лечащий врач. - 2008. - № 2. - С. 22-25. 
Огляди літератури, оригінальні дослідження, погляд на проблему, ювілеї

6. Кадурина Т. И. Наследственные коллагенопатии: клиника, диагностика, лечение, диспансеризация. СП6. : Невский диалект, 2000. - 271 с.

7. Мітченко О. І. Гіпертрофія міокарда лівого шлуночка у хворих з артеріальною гіпертензією на тлі метаболічного синдрому, зв'язок із факторами серцево-судинного ризику / О. І. Мітченко, Г. Б. Каспрук, В. Ю. Романов //Укр. кардіол. журн. -2010.- Додаток 1.C. 22-27.

8. Сіренко Ю. М. Гіпертрофія лівого шлуночка: методи оцінки, можливості регресування / Ю. М. Сіренко // Артериальная гипертензия. - 2010. - № 4 (12). - С. 82-90.

9. Сіренко Ю.М. Артеріальна гіпертензія та супутня патологія / Ю. М. Сіренко. - Донецьк : Видавець Заславський О. Ю., 2010. - 384 с.

10. Сидорчук Л. П. Вплив тривалого фармакогенетичного детермінованого лікування на показники ехокардіографії та геометричні моделі міокарда лівого шлуночка у хворих з артеріальною гіпертензією / Л. П. Сидорчук, К. М. Амосова // Укр. кардіол. журн. 2010. - № 5. - С. 30-41.

11. Акимов А. Г. Перспективы применения миокардиальных цитопротекторов в кардиологической практике / А. Г. Акимов, В. Ю. Полумисков // Тегга medica nova. - 2005. - № 3, Часть 1. - С. 10-15.

12. Пархоменко А. Н. Жизнеспособный миокард и кардиоцитопротекция: возможности метаболической терапии при острой и хронической формах ишемической болезни сердца / А. Н. Пархоменко // Укр. мед. часопис. - 2001. - № 3 (23). - С. 5-11.

13. Past and present course of cardioprotection against ischemia/reperfusion injury / D. Liem, H. Honda, J. Zhang [et al.] // J. Appl. Physiol. - 2007. - Vol. 103. P. 2129-2136.

\section{REFERENCES}

1. (2017). Derzhavna sluzhba statystyky Ukrainy: Demohrafichna ta sotsialna statystyka. Okhorona zdorovia. Zakhvoriuvanist naselennia (za danymy Ministerstva okhorony zdorovia) [The State Statistics Service of Ukraine: Demographic and Social Statistics. Healthcare The incidence of the population (according to the Ministry of Health). Retrieved from: http://www.ukrstat.gov.ua [in Ukrainian].

2. Kovalenko, V.M., \& Kornatskyi, V.M. (Eds.). (2017). Problema zdorovia i tryvalosti zhyttia v suchasnykh umovah [The problem of health and life expectancy in modern conditions]. Kyiv [in Ukrainian].

3. Koval, S.M., Bozhko, V.V., \& Penkova, M.Yu. (2010). Hiperurikemiia ta sumarnyi ryzyk uskladnen u patsiientiv z hipertonichnoiu khvoroboiu [Hyperuricemia and total risk of complications in hypertensive patients (according to clinical data)]. Ukrainskyi revmatolohichnyi zhurnal - Ukrainian Rheumatological Journal, 4, 42-48 [in Ukrainian].

4. Zaremba, Ye.H., Rak, N.O., \& Hrib, N.V. (2017). Zviazok mizh nedyferentsiiovanoiu dysplaziieiu spoluchnoi tkanyny ta arterialnoiu hipertenziieiu [Relationship between undifferentiated connective tissue dysplasia and arterial hypertension]. Zdorovia i suspilstvo - Health and Society, 1-2, 139140 [in Ukrainian].

5. Nechayeva, G.I., Yakovlev, V.M., \& Konev, V.P. (2008). Displaziya soyedinitelnoy tkani: osnovnye klinicheskie sindromy, formulirovka diagnoza, lechenie [Dysplasia of the connective tissue: the main clinical syndromes, the formulation of the diagnosis, treatment]. Lechashchiy vrach - Attending Physician, 2, 22-25 [in Russian].

6. Kadurina, T.I. (2000). Nasledstvennye kollagenopatii: klinika, diagnostika, lechenie, dispanserizatsiya [Hereditary collagenopathies: clinic, diagnosis, treatment, clinical examination]. Saint-Petersburg: Nevskiy dialekt [in Russian].

7. Mitchenko, O.I., Kaspruk, H.B., \& Romanov, V.Yu. (2010). Hipertrofiia miokarda livoho shlunochka u khvorykh z arterialnoiu hipertenziieiu na tli metabolichnoho syndromu, zviazok iz faktoramy sertsevo-sudynnoho ryzyku [Left ventricular myocardial hypertrophy in patients with arterial hypertension against metabolic syndrome, association with cardiovascular risk factors]. Ukr. kardiol. Zhurn. - Ukrainian Cardiologic Journal, 1, 22-27 [in Ukrainian].

8. Sirenko, Yu.M. (2010). Hipertrofiia livoho shlunochka: metody otsinky, mozhlyvosti rehresuvannia [Left ventricular hypertrophy: evaluation methods, regression posibilities]. Arterialnaya gipertenziya - Arterial Hypertension, 4 (12), 82-90 [in Ukrainian].

9. Sirenko, Yu.M. (2010). Arterialna hipertenziia ta suputnia patolohiia [Arterial hypertension and concomitant pathology]. Donetsk: Vydavets Zaslavskyi O.Yu. [in Ukrainian].

10. Sydorchuk, L.P., \& Amosova, K.M. (2010). Vplyv tryvaloho farmakohenetychnoho determinovanoho likuvannia na pokaznyky ehokardiohrafii ta heometrychni modeli miokarda livoho shlunochka u khvorykh z arterialnoiu hipertenziieiu [Influence of long-term pharmacogenic deterministic treatment on echocardiography and geometric models of left ventricular myocardium in patients with arterial hypertension]. Ukr. kardiol. Zhurn - Ukrainian Cardiologic Journal, 5, 30-41 [in Ukrainian].

11. Akimov, A.G., \& Polumiskov, V.Yu. (2005). Perspektivy primeneniya miokardialnykh tsitoprotektorov v kardiologicheskoy praktike [Prospects for the use of myocardial cytoprotectors in cardiological practice]. Terra Medica Nova, 3, 10-15 [in Russian].

12. Parkhomenko, A.N. (2001). Zhiznesposobnyy miokard i kardiotsitoprotektsiya: vozmozhnosti metabolicheskoy terapii pri ostroy i khronicheskoy formakh ishemicheskoy bolezni serdtsa [Viable myocardium and cardiocytoprotection: the possibilities of metabolic therapy in acute and chronic forms of coronary heart disease]. Ukr. med. Chasopys - Ukrainian Medical Journal, 3 (23), 5-11 [in Russian].

13. Liem, D., Honda, H., \& Zhang, J. (2007). Past and present course of cardioprotection against ischemia/reperfusion injury. J. Appl. Physiol., 103, 2129-2136. 


\title{
Огляди літератури, оригінальні дослідження, погляд на проблему, ювілеї ОПТИМАЛЬНЫЙ МЕТОД ЛЕЧЕНИЯ АРТЕРИАЛЬНОЙ ГИПЕРТЕНЗИИ, СОЧЕТАННОЙ
С ДИСПЛАЗИЕЙ СОЕДИНИТЕЛЬНОЙ ТКАНИ
}

\author{
๑Е. Х. Заремба, В. М. Карпляк, Н. О. Рак, А. В. Заремба-Федчишин, О. В. Заремба \\ Львовский национальный медицинский университет имени Данила Галицкого
}

РЕзЮМЕ. Артериальная гипертензия (АГ) является одним из самых агрессивных факторов риска формирования и прогрессирования патологии сердечно-сосудистой системы (ССС) с поражением органов-мишеней и развитием ассоциированных заболеваний: ишемической болезни сердца, острой и хронической церебральной патологии, системного атеросклероза, поражения клубочкового аппарата почек с развитием нефропатии и почечной недостаточности.

Цель исследования - улучшить эффективность лечения больных АГ, сочетанной з ДСТ, на основании изучения клинического течения, выраженности внешних и внутренних фенотипических признаков ДСТ, активности воспаления, системы свертывания крови с применением комбинации ИАПФ и БКК с использованием метаболической терапии в комплексном лечении.

Материал и методы. Обследовано 57 больных (24 женщины и 33 мужчины) АГ ІІ - ІІІ стадии с проявлениями ДСТ. Больные были поделены на 3 группы: І группа (основная) - 35 больных, которые, кроме базисной терапии, получали 2-этил-6-метил-3-гидроксипиридина сукцинат (мексикор); II группа (сравнения) - 22 больных, получавших базисную терапию согласно клиническому протоколу; III группа - 20 практически здоровых лиц. В базисную терапию, среди гипотензивных средств, входила комбинация рамиприла/амлодипина (хартила-АМ) с титрацией дозы в зависимости от исходных уровней АД, суточного мониторинга артериального давления (СМАД). Обследование больных проводили согласно разработанному нами протоколу: объективный осмотр, лабораторные исследования (коагулограмма: протромбиновое время (ПВ), протромбиновый индекс (ПИ) и общий фибриноген (СФ), определение С-реактивного протеина (СРП)), инструментальные методы обследования (ЭКГ, эхоКГ, СМАД, УзИ внутренних органов и сосудов нижних конечностей, Уз дуплексное обследование сонных и позвоночных артерий, рентгенологическое исследование костно-суставной системы), консультации офтальмолога, невропатолога, травматолога, стоматолога.

Результаты. В результате проведенного исследования у больных АГ ІІ - III стадий диагностирована ДСТ различной степени выраженности. В I группе больных ДСТ средней степени тяжести выявлена у 30 (85,7 \%), во II группе - у 20 (90,9%), тяжелой степени выраженности - у 5 (14,3\%) и 2 (9,1 \%) пациентов соответственно.

Результаты исследования показали, что до 10 суток лечения в основной группе среднесуточные САД и ДАД снижались на 15,6 \% и 17,5 \% соответственно, а до 30 суток - на 25,2 \% и 26,4 \%. После применения рамиприла/амлодипина и 2-этил-6-метил-3-гидроксипиридина сукцината в комплексном лечении больных АГ, сочетанной с ДСТ, уровень СРП снизился на 42,79\% на 10 день лечения $(p<0,01)$ и в 2 раза после 30 дней наблюдения. Достоверно из-

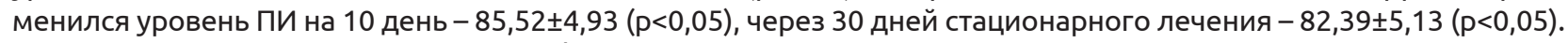

Выводы. Применение рамиприла/амлодипина и 2-этил-6-метил-3-гидроксипиридина сукцината в комплексном лечении больных АГ, сочетанной с ДСТ, улучшает клиническое течение заболевания, уменьшает частоту рецидивов гипертонических кризов, снижает количество осложнений, приводит к уменьшению сроков стабилизации АД, способствует нормализации СРП и показателей системы свертывания крови.

КЛЮЧЕВЫЕ СЛОВА: артериальная гипертензия; дисплазия соединительной ткани; рамиприл/амлодипин; 2-этил-6-метил-3-гидроксипиридина сукцинат.

\section{OPTIMAL METHOD OF TREATMENT OF ARTERIAL HYPERTENSION COMBINED WITH DYSPLASIA OF CONNECTIVE TISSUE}

\author{
@E. H. Zaremba, V. M. Karplyak, N. O. Rak, O. V. Zaremba-Fedchyshyn, O. V. Zaremba \\ Danylo Halytskyi Lviv National Medical University
}

SUMMARY. Arterial hypertension (AH) is one of the most aggressive risk factors for the formation and progression of the pathology of the cardiovascular system (CVS) with lesions of the target organs and the development of associated diseases: coronary heart disease, acute and chronic cerebral pathology, systemic atherosclerosis, lesion of the glomerular kidney system with the development of nephropathy and renal failure.

The aim of the study - to improve the efficiency of treatment of patients with hypertension combined with connective tissue dysplasia (CTD) based on the study of clinical course, the severity of external and internal phenotypic signs of CTD, inflammation activity, blood clotting systems using the combination of ACE inhibitors and CCB using metabolic therapy in a complex treatment.

Material and Methods. We examined 57 patients ( 24 women and 33 men) at the AH II - III stages with manifestations of CTD. The patients were divided into 3 groups: the group I (main) - 35 patients who, in addition to the baseline therapy, 
Огляди літератури, оригінальні дослідження, погляд на проблему, ювілеї

received 2-ethyl-6-methyl-3-hydroxypyridine succinate (мexicor); group II (comparison) - 22 patients who received basic therapy according to the clinical protocol; group III - 20 practically healthy persons. In the baseline therapy among antihypertensive agents was a combination of ramipril/amlodipine (hartyl-AM) with titration of dose depending on baseline blood pressure levels, daily blood pressure monitoring (DBPM). Patient examination was carried out in accordance with the protocol developed by us: objective review, laboratory tests (coagulogram: prothrombin time (PT), prothrombin index (PI) and total fibrinogen (TF), determination of C-reactive protein (CRP)), instrumental examination methods (ECG, echocardiography, DMAP, ultrasound examination of the internal organs and vessels of the lower extremities, ultrasound duplex examination of the sleep and vertebral arteries, $\mathrm{X}$-ray examination of the bone and articular system), consultation of an ophthalmologist, a neuropathologist, a traumatologist, a dentist.

Results. As a result of the research conducted in patients with hypertension II-III stage diagnosis of CTD of varying degrees of severity. In the group I of patients with CTD of average severity 30 (85.7 \%), in the group II - in 20 (90.9 \%), severe severity was observed - in 5 (14.3\%) and 2 (9.1\%) patients respectively.

The results of the study showed that up to 10 days of treatment in the main group, the average daily SAT and DAT decreased by $15.6 \%$ and $17.5 \%$ respectively, and up to 30 days - by $25.2 \%$ and $26.4 \%$. After application of ramipril/ amlodipine and 2-ethyl-6-methyl-3-hydroxypyridine succinate in the complex treatment of patients with hypertension associated with CTD, the CRP level decreased by $42.79 \%$ for 10 days of treatment $(p<0.01)$ and 2-fold after 30 days of observation. The level of PI for 10 days has significantly changed $-(85.52 \pm 4.93)(p<0.05)$, after 30 days of inpatient treatment $-(82.39 \pm 5.13)(p<0.05)$.

Conclusions. The use of ramipril/amlodipine and 2-ethyl-6-methyl-3-hydroxypyridine succinate in the complex treatment of patients with hypertension combined with CTD improves the clinical course of the disease, reduces the incidence of relapses of hypertensive crises, reduces the number of complications, reduces the timing of stabilization of blood pressure, promotes normalization CRP and blood coagulation indexes.

KEY WORDS: arterial hypertension; connective tissue dysplasia; ramipril/amlodipine; 2-ethyl-6-methyl-3hydroxypyridine succinate. 